\title{
Pengaruh Stress Kerja Dan Emotional Intelligence Terhadap Turnover Intention Internal Auditor
}

\author{
Hardi Hermawan Prasetya ${ }^{1}$ \\ Fakultas Ekonomi dan Bisnis \\ Universitas Udayana, Indonesia. \\ Email: hardihermawan848@gmail.com
}

\author{
Dodik Ariyanto ${ }^{2}$ \\ Fakultas Ekonomi dan Bisnis \\ Universitas Udayana, Indonesia.
}

\begin{abstract}
ABSTRAK
Tujuan dari penelitian adalah menganalisis stress kerja dan emotional intelligence terhadap turnover intention auditor internal di PT Bank BRI. Penelitian dilakukan di 29 kantor pada PT Bank BRI Wilayah Bali-Nusra tahun 2019. Responden penelitian auditor sebanyak 107. Teknik penyempelan dengan metode sample jenuh. Pengumpulan data dilakukan dengan menyebarkan kuesioner dan data yang kembali sebanyak 96 orang auditor. Data di uji teknik analisis regresi linear berganda. Berdasarkan hasil analisis, variabel stress kerja berpengaruh signifikan terhadap turnover intention internal auditor di PT Bank BRI Kantor Wilayah Denpasar dengan nilai signifikansi sebesar 0,000 $<0,05$ maka $\mathrm{H}_{1}$ diterima. Emotional intelligence berpengaruh signifikan terhadap turnover intention internal auditor di PT Bank BRI Kantor Wilayah Denpasar dengan nilai signifikansi sebesar 0,004 $<0,05$ maka $\mathrm{H}_{1}$ diterima.
\end{abstract}

Kata Kunci: Stress Kerja; Emotional Intelligence; Turnover Intention.

\section{Effect of Job Stress and Emotional Intelligence on Internal Auditor Turnover Intention}

\begin{abstract}
The purpose of the study was to analyze work stress and emotional intelligence on the turnover of the intention of internal auditors at PT Bank BRI. The study was conducted in 29 offices at PT Bank BRI BaliNusra Region in 2019. The auditor's research respondents were 107. Complementary techniques with saturated sample methods. Data collection was carried out by distributing questionnaires and returning data as many as 96 auditors. Data was tested by multiple linear regression analysis techniques. Based on the results of the analysis, the work stress variable has a significant effect on the auditor's internal turnover intention at PT Bank BRI Denpasar Regional Office with a significance value of $0.000<0.05, \mathrm{H} 1$ is accepted. Emotional intelligence has a significant effect on internal auditor turnover intention at PT Bank BRI Denpasar Regional Office with a significance value of $0.004<0.05$, H1 is accepted.
\end{abstract}

Keywords: $\quad$ Stress Of Work; Emotional Intelligence; Turnover Intention.

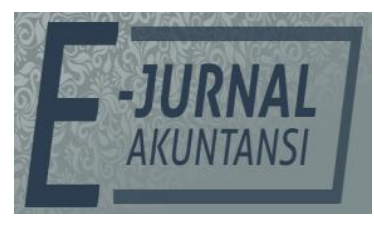

E-JA

e-Jurnal Akuntansi e-ISSN 2302-8556

Vol.298 No. 1

Denpasar, Oktober

2019

Hal. 356-371

Artikel masuk:

25 Juni 2019

Tanggal diterima:

09 Agustus 2019 


\section{PENDAHULUAN}

Bank mempunyai peranan sangat penting dalam menggerakkan roda perekonomian suatu negara, serta sebagai lembaga keuangan yang usaha pokoknya memberikan kredit kepada pihak yang memerlukan dana (Kasmir, 2014:62). Pendapatan perbankan diperoleh terutama dari penjualan produk perbankan. Salah satu pendapatan perbankan yaitu dengan menyediakan jasa perkreditan yang berupa selisih bunga kredit, provisi dan komisi (Eko, 2014).

Fenomena yang sering terjadi di perbankan dalam penyaluran kredit adalah timbulnya kredit macet atau kredit bermasalah. Kredit macet atau kredit bermasalah merupakan suatu penyakit yang dapat menganggu dan mengancam sistem kegiatan bank, sehingga bank menjadi tidak sehat. Masalah ini timbul karena faktor ekonomi serta krisis global atau ada kesengajaan dengan membuat kredit fiktif yang dilakukan oleh karyawan bank seperti kecurangan (fraud) yang diartikan sebagai perbuatan curang yang dilakukan dengan berbagai cara licik dan bersifat menipu serta sering tidak disadari oleh korban yang dirugikan, dalam mengatasi terjadinya kecurangan (fraud) dibentuk audit internal sebagai biro pengawasan untuk mencegah kecurangan dalam suatu perusahaan yang kegiatannya meliputi menguji dan menilai efektivitas serta kecukupan sistem pengendalian internal yang ada dalam perusahaan.

Kasus seperti ini harus diselesaikan oleh seorang auditor internal dalam penanganannya mendapatkan tekanan yang begitu besar dalam membuat laporan temuan audit, sehingga auditor tidak lepas dari ancaman, dari terror yang terus dilakukan oleh pelaku yang menyebabkan auditor merasa takut sehingga melalukan tindakan turnover intention (Sumber: Kompas.com, 2018).

Turnover intention merupakan salah satu bentuk perilaku menarik diri (withdrawal) dalam dunia kerja, akan tetapi sekaligus juga merupakan hak bagi setiap individu untuk menentukan pilihannya apakah tetap bekerja atau keluar dari perusahaan tersebut (Brunetto et al. 2012). Tingginya tingkat turnover intention pada auditor akan menimbulkan dampak negatif bagi perusahaan yang dapat menciptakan ketidak stabilan dan ketidak pastian terhadap kondisi tenaga kerja serta dalam peningkatan sumber daya manusia. Keinginan auditor internal untuk berpindah (turnover intentions) mengacu pada hasil evaluasi terhadap hasil audit yang dilaporkan mengenai kelanjutan hubungan dengan perusahaan yang belum diwujudkan (Cheng \& Franz, 2013).

Kecurangan (fraud) di perbankan lebih banyak melibatkan pihak intern bank (Indri \& Sukartha, 2017). Unsur-unsur yang melatarbelakangi tindakan fraud ini antara lain adanya hal yang tidak terduga (surprise), pencurian (theft), tipu daya (trickery), licik (cunning), penyembunyian (concealment), dan pengubahan (conversion) (Sulastri et al., 2015). Pengawasan intern dapat diketahui apakah suatu perusahaan telah melaksanakan kegiatan sesuai dengan tugas dan fungsinya secara efektif dan efisien, serta sesuai dengan rencana, kebijakan yang telah ditetapkan. Selain itu, pengawasan intern diperlukan untuk mendorong terwujudnya good governance dan clean government dan mendukung pengawasan perusahaan yang efektif, efisien, transparan, akuntabel serta bersih dan bebas dari praktik korupsi, kolusi dan nepotisme (Balkish et al., 2013).

Pengendalian atas aktivitas operasi bank meliputi pengendalian eksternal bank dan pengendalian internal bank. Pengendalian eksternal bank adalah 
berupa pemeriksaan kinerja bank umum oleh Bank Indonesia sebagai bank sentral serta pemeriksaan laporan keuangan bank umum oleh akuntan publik (Alvin et al., 2008:1). Adapun pengendalian internal bank umum berupa pengendalian atau kontrol yang akan diterapkan dalam sistem prosedur kegiatan operasional bank dan pemeriksaan intern secara berkala oleh auditor internal atas pelaksanaan aktivitas usaha bank berdasarkan pada Standar Pelaksanaan Fungsi Intern Bank (SPFAIB) tahun 1999 (Alvin et al., 2008:2).

Mulyadi (2011:112) berpendapat dalam Standar Pelaksanaan Fungsi Intern Bank (SPFAIB) tahun 1999, auditor internal adalah auditor yang bekerja dalam perusahaan (perusahaan negara maupun perusahaan swasta) yang tugas pokoknya adalah menentukan apakah kebijakan dan prosedur yang ditetapkan oleh manajemen puncak telah dipatuhi, menentukan baik atau tidaknya penjagaan terhadap kekayaan organisasi, menentukan efisiensi dan efektivitas prosedur kegiatan organisasi, serta menentukan keandalan informasi yang dihasilkan oleh berbagai bagian organisasi.

Seseorang baru dapat menjadi auditor internal jika mempunyai pengetahuan yang memadai dalam bidang tugasnya, memiliki kemampuan mempertahankan kualitas profesionalnya melalui pendidikan profesi lanjutan yang berkesinambungan serta dapat berkomunikasi dengan baik lisan maupun tulisan (Indri \& Sukartha, 2017).

Pemeriksaan internal atau internal auditing merupakan tugas dari auditor internal. Peran auditor internal sangatlah penting dalam memberikan kontribusi kepada pihak manajemen dimana aktivitas audit tidak lagi terfokus kepada keuangan perusahaan, namun juga telah banyak terlibat ke dalam bidang operasional antara lain seperti produksi, penjualan, distribusi personil, dan lain sebagainya di samping untuk peningkatan efisiensi dan efektifitas kegiatan perusahaan (Kasmir, 2008:2-3). Auditor internal dituntut untuk melakukan pekerjaannya secara profesional, yakni dengan menjunjung tinggi standar mutu pekerjaan dan menaati kode etik profesi.

PT Bank BRI Kanwil Denpasar, dalam mengatasi terjadinya kecurangan (fraud) dibentuk audit internal yang berperan di lingkungan perbankan sebagai pelaksana dari biro pengawasan dalam melakukan tugasnya tentunya juga tidak terlepas dari terjadinya konflik-konflik kepentingan, baik itu antar individu, antar departemen maupun antar individu dan perusahaan (Kasmir, 2014:112). Berbagai tekanan maupun konflik yang dialami oleh seorang internal auditor pada akhirnya akan bermuara pada terjadinya stress kerja (David et al., 2013). Stress kerja ini mempunyai akibat yang umumnya negatif seperti menurunnya kualitas hasil kerja, rendahnya loyalitas auditor pada perusahaan sehingga terjadinya perilaku turnover intention (Edwin, 2017). Hal ini berdasarkan penelitian yang dilakukan oleh Frengky (2012). Stress kerja yang terjadi pada akhirnya juga akan berpengaruh pada perilaku turnover intention auditor secara keseluruhan. Shaini \& Wijana (2017) menyatakan stress kerja memiliki pengaruh terhadap perilaku turnover intention auditor. Muhammad et al. (2017) membuktikan bahwa terdapat pengaruh positif stress kerja terhadap perilaku turnover intention auditor. Panagiotis et al. (2017) perilaku turnover intention auditor dipengaruhi oleh stress kerja yang dialami oleh auditor. 
Perilaku turnover intention auditor sebagai perilaku yang menyimpang dari seorang auditor tentu saja dipengaruhi oleh beberapa faktor diluar stress kerja, antara lain adalah emotional intelligence (Shaini \& Wijana, 2017). Emotional intelligence (EI) adalah kemampuan mengenali perasaan diri sendiri dan perasaan orang lain, memotivasi diri sendiri serta mengelola emosi dengan baik pada diri sendiri dan dalam hubungan dengan orang lain (Jichul \& Thomas, 2016). Emotional intelligence menuntut diri untuk belajar mengakui dan menghargai perasaan diri sendiri dan orang lain serta untuk menanggapinya dengan tepat, menerapkan dengan efektif energi emosi dalam kehidupan dan pekerjaan seharihari. Pada kenyataannya perlu diakui bahwa emotional intelligence memiliki peran yang sangat penting untuk mencapai kesuksesan diperusahaan, tempat kerja dan berkomunikasi di lingkungan masyarakat (Frengky, 2012).

Begitu pentingnya hasil temuan audit internal yang diberikan oleh auditor bagi sebuah perusahaan, maka seorang internal auditor dituntut untuk menghindari terjadinya perilaku turnover intention. Gina \& Tamari (2015) menyatakan pentingnya emotional intelligence membentuk bagian penting dari reaksi keseluruhan terhadap stres dan kelelahan yang dihadapi oleh auditor sehingga mampu menurunkan tingkat turnover intention, oleh karena itu seorang auditor harus melaksanakan emotional intelligence sehingga auditor dapat menggunakan kemahiran profesionalnya dengan cermat dan seksama untuk menghindari stress kerja dan menurunkan perilaku turnover intention (Sudarshan, 2015).

Auditor internal merupakan suatu profesi yang sangat penting untuk dikaji, dalam hal ini perilaku turnover intention auditor perlu dihindari sebagai tanggung jawab dalam melaksanakan pengawasan audit, sehingga dalam hal ini emotional intelligence perlu dilaksanakan untuk menghindari terjadinya stress kerja dan perilaku turnover intention auditor internal untuk meningkatkan hasil laporan audit.

Berdasarkan kajian teoritis dan empiris, maka masalah dalam penelitian ini adalah 1) Apakah stress kerja berpengaruh pada perilaku turnover intention internal auditor di PT Bank BRI Kantor Wilayah Denpasar, 2) Apakah emotional intelligence berpengaruh pada perilaku turnover intention internal auditor di PT Bank BRI Kantor Wilayah Denpasar.

Teori disonansi menjelaskan bahwa ketidaksesuaian memotivasi seseorang untuk mengurangi atau mengeliminasi ketidaksesuaian tersebut. Sedangkan Functional Theory dari perubahan sikap menyatakan bahwa sikap berlaku untuk memenuhi kebutuhan seseorang (Desmond et al., 2012). Sesuai dengan dissonance theory maka pemeriksa tersebut akan berupaya mengeliminasi ketidaksesuaian dengan membuat prioritas dan menghilangkan sesuatu yang dianggap tidak begitu penting, sehingga dapat menimbulkan suatu perilaku yang menyimpang dalam penugasan pemeriksaannya, seperti penghentian prosedur pemeriksaan dan kesalahan dalam tahapan-tahapan (prosedur) pemeriksaan. Berdasarkan functional theory, seorang pemeriksa dapat melakukan tindakan apapun termasuk perilaku menyimpang untuk memenuhi kebutuhannya, sehingga dengan sendirinya dapat menurunkan kualitas pemeriksaan yang akan dihasilkan (Mahatma \& Suaryana, 2016).

Profesi Auditor 
Menurut Mulyadi (2011:87) auditor dapat dibedakan menjadi tiga jenis, antara lain: 1) auditor pemerintah adalah auditor yang bertugas melakukan audit atas keuangan Negara pada instansi-instansi pemerintah. Di Indonesia audit ini dilakukan oleh Badan Pemeriksaan Keuangan (BPK). 2) eksternal auditor atau akuntan publik adalah seorang praktisi dan gelar professional yang diberikan kepada akuntan di Indonesia yang telah mendapat izin untuk memberikan jasa audit umum dan review atas laporan keuangan, audit kinerja, dan audit khusus serta jasa nonassurancce seperti jasa konsultasi, jasa kompilasi, jasa perpajakan. 3) internal auditor merupakan auditor yang bekerja suatu perusahaan dan oleh karenanya berstatus sebagai pegawai pada perusahaan tersebut. Tugas utamanya ditujukan untuk membantu manajemen perusahaan tempat dimana ia bekerja.

Audit Internal mempunyai peranan yang sangat penting dalam mencapai tujuan perusahaan yang telah ditentukan. Perlunya konsep Audit internal dikarenakan bertambah luasnya ruang lingkup perusahaan. Audit internal yang memberikan nilai, mengatur badan dan manajemen senior sebagai sumber tujuan saran independen. Adapun menurut Tugiman (2006:221) audit internal adalah: "Internal audit adalah pemeriksaan yang dilakukan oleh bagian internal audit perusahaan, baik terhadap laporan keuangan dan catatan akuntansi perusahaan, maupun ketaatan terhadap kebijakan manajemen puncak yang telah ditentukan dan ketaatan terhadap peraturan pemerintah dan ketentuanketentuan dari ikatan profesi yang berlaku.

Turnover Intention dapat diartikan sebagai pergerakan tenaga kerja keluar dari organisasi. Turnover menurut Robbins \& Judge (2011:38) adalah tindakan pengunduran diri secara permanen yang dilakukan oleh karyawan baik secara sukarela ataupun tidak secara sukarela. Turnover dapat berupa pengunduran diri, perpindahan keluar unit organisasi, pemberhentian atau kematian anggota organisasi. Jichul \& Thomas (2017) menyebutkan turnover intention merupakan prediktor terbaik untuk mengindentifikasi perilaku turnover yang akan terjadi pada karyawan suatu organisasi.

Robbins \& Judge (2011: 181-182) menyatakan indikator-indikator yang mempengaruhi terjadinya turnover cukup kompleks dan saling berkaitan satu sama lain. Diantara indikator-indikator tersebut yang akan dibahas antara lain sebagai berikut: 1) usia, tingkat turnover yang cenderung lebih tinggi pada karyawan berusia muda (Edwin, 2017). 2) lama kerja, semakin lama masa kerja semakin rendah kecenderungan turnovernya. Turnover lebih banyak terjadi pada karyawan dengan masa kerja lebih singkat. 3) tingkat pendidikan dan intellegensi yang tidak terlalu tinggi akan memandang tugas-tugas yang sulit sebagai tekanan dan sumber kecemasan yang disebut dengan out-group. 4) keterikatan terhadap perusahaan yang kuat terhadap perusahaan tempat ia bekerja berarti mempunyai dan membentuk perasaan memiliki (sense of belonging), rasa aman, efikasi. 5) Akibat secara langsung adalah menurunnya dorongan diri untuk berpindah pekerjaan dan perusahaan (Panagiotis et al., 2017).

Kreitner \& Kinicki (2008:351) mendefinisikan stress kerja sebagai respon adaptif yang dihubungkan oleh karaktersitik atau melalui proses psikologis individu, yang merupakan suatu konsekuensi dari setiap tindakan eksternal, 
situasi, atau peristiwa yang menempatkan tuntutan psikologis/fisik khusus pada seseorang. Edwin (2017) menyebutkan bahwa karakteristik pekerjaan yang menyebabkan sumber stres kerja secara konseptual terdiri dari lima dimensi, yaitu sebagai berikut: 1) physical environment, lingkungan tempat bekerja yang tidak mendukung terselenggaranya proses bekerja yang baik. 2) role conflict, mengindikasikan suatu tingkatan dimana individu mengalami ketidaksesuaian antara permintaan dan komitmen dari suatu peran. 3) role ambiguity, mengindikasikan suatu tingkatan dimana kriteria prioritas, harapan (expectations), dan evaluasi tidak disampaikan secara jelas kepada pegawai. 4) role overload, mengindikasikan suatu tingkatan dimana permintaan kerja melebihi kemampuan pegawai dan sumber daya lainnya, serta suatu keadaan dimana pegawai tidak mampu menyelesaikan beban kerja yang direncanakan. 5) role insufficiency, mengindikasikan suatu kondisi dimana pendidikan, training, keterampilan, dan pengalaman pegawai tidak sesuai dengan job requirements

Pengertian emotional intelligenci kecerdasan atau inteligensi menurut Casmini (2007:14) dapat didefinisikan melalui dua jalan yaitu secara kuantitatif adalah proses belajar untuk memecahkan masalah yang dapat diukur dengan tes inteligensi, dan secara kualitatif suatu cara berpikir dalam membentuk konstruk bagaimana menghubungkan dan mengelola informasi dari luar yang disesuaikan dengan dirinya. Edwin. (2017) menyatakan terdapat beberapa indikatorindikator yang mempengaruhi emotional intelligenci (EI) diantaranya yaitu: 1) kesadaran diri, yakni kemampuan untuk mengenal dan memilah-milah perasaan, memahami hal yang sedang kita rasakan dan mengapa hal itu kita rasakan, dan mengetahui penyebab munculnya perasaan tersebut, serta pengaruh perilaku kita terhadap orang lain. 2) pengaturan diri, ialah menangani emosi sedemikian rupa sehingga berdampak positif kepada pelaksanaan tugas, peka terhadap kata hati dan sanggup menunda kenikmatan sebelum tercapainya satu gagasan, maupun pulih kembali dari tekanan emosi. 3) motivasi, ialah menggunakan hasrat yang paling dalam untuk menggerakkan dan menuntut kita menuju sasaran, membantu kita mengambil inisiatif dan bertindak sangat efektif, serta untuk bertahan menghadapi kegagalan dan frustasi. 4) empati ialah merasakan yang dirasakan oleh orang lain, mampu memahami perspektif mereka, menumbuhkan hubungan saling percaya dan menyelaraskan diri dengan bermacam-macam orang. 5) keterampilan sosial ialah menangani emosi dengan baik ketika berhubungan dengan orang lain dan dengan cermat membaca situasi dan berinteraksi dengan lancar, serta untuk bekerja sama dan bekerja dalam team.

Teori Perubahan sikap (Attitude change theory) merupakan model yang sering digunakan dalam menjelaskan hubungan antara stress kerja dan hasil pekerjaan (Alan \& Todd, 2011). Menurut Robbins \& Judge (2011:97) perilaku yang berlebihan akan menempatkan tuntutan yang tidak dapat dicapai, yang mengakibatkan hasil pekerjaan menurun. Hal ini relevan dengan kejenuhan kerja sangat besar akan menyebabkan tingkat stres yang tinggi yang berpengaruh terhadap karakteristik personal auditor sehingga melakukan perilaku disfungsional audit (Cheng \& Franz, 2013). Dari penjelasan di atas, maka hipotesis yang dapat dirumuskan adalah sebagai berikut:

$\mathrm{H}_{1}$ : Stress kerja berpengaruh positif pada turnover intention internal auditor. 
Teori disonansi kognitif dapat menjelaskan bahwa emotional intelligence merupakan upaya dalam memecahkan masalah moral dengan menggunakan logika yang sehat. Dalam berlogika secara sehat seseorang harus mampu memahami dengan baik masalah yang sedang dihadapi sebelum memutuskan pemecahan masalah seperti apa yang akan diambilnya sehingga memiliki hasil yang berkualitas dan menghindari terjadinya perilaku disfungsional auditor (Sartika, 2013). Berdasarkan uraian tersebut maka hipotesis yang diajukan adalah sebagai berikut:

$\mathrm{H}_{2}$ : Emotional intelligence berpengaruh negatif pada turnover intention internal auditor.

\section{METODE PENELITIAN}

Berdasarkan permasalahan yang diteliti, penelitian ini digolongkan pada penelitian asosiatif (hubungan), yaitu penelitian yang bertujuan untuk mengetahui hubungan dari variabel atau lebih (Sugiyono, 2017 :5).

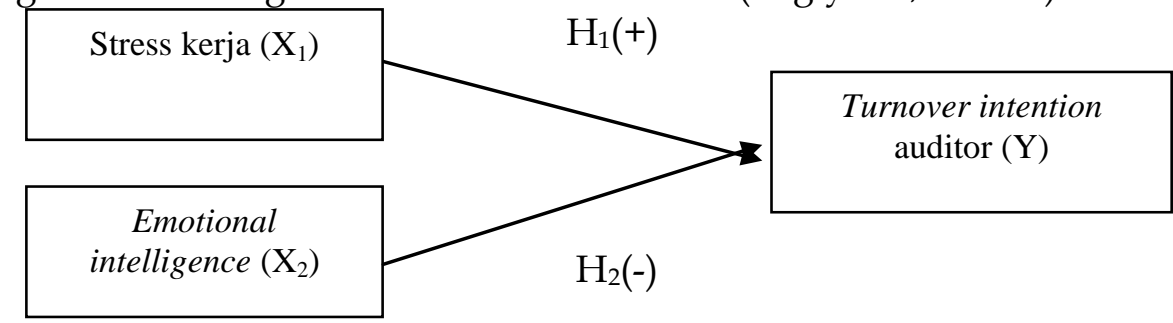

Sumber: Data Penelitian, 2019

Gambar 2. Desain Penelitian

Objek penelitian dalam penelitian ini adalah turnover intention internal auditor pada PT. Bank BRI Kanwil Denpasar yang dipengaruhi oleh stress kerja dan emotional intelligence.

Variabel merupakan suatu sifat yang dapat memiliki berbagai macam nilai. Berdasarkan hipotesis yang telah dikemukakan, maka variabel yang akan dianalisis dikelompokkan sebagai berikut. Variabel bebas $(X)$, variabel bebas dalam penelitian ini adalah stress kerja $\left(X_{1}\right)$ dan emotional intelligence $\left(X_{2}\right)$. Variabel terikat $(\mathrm{Y})$, variabel terikat dalam penelitian ini adalah turnover intention internal auditor.

Kreitner dan Kinicki (2008:351) mendefinisikan stress kerja sebagai respon adaptif yang dihubungkan oleh karaktersitik dan psikologis individu, yang merupakan suatu konsekuensi dari setiap tindakan eksternal, situasi, atau peristiwa yang menempatkan tuntutan psikologis/fisik pada seseorang. Penelitian ini menggunakan empat indikator yang dikembangkan oleh (Nikolaou \& Tesaousis, 2002) yaitu sebagai berikut hubungan kerja, dimana tingkat stress yang dialami oleh seorang auditor terhadap hubungan kerjasama yang kurang baik dengan rekan sekantor. Pekerjaan yang overload, dimana tingkat stress yang dialami oleh seorang auditor terhadap pekerjaan yang terlalu banyak. Kontrol, dimana tingkat stress yang dialami oleh seorang auditor terhadap kurangnya kontrol dalam melaksanakan pekerjaan. Sumber daya, dimana tingkat stress yang dialami oleh seorang auditor terhadap kurangnya peralatan yang mendukung pekerjaan. Benefit, dimana tingkat stress yang 
dialami oleh seorang auditor terhadap tuntutan pekerjaan yang tidak sesuai dengan benefit yang diterima.

Istilah Emotional intelligence adalah suatu kemampuan yang dimiliki oleh individu untuk dapat menggunakan perasaannya secara optimal guna mengenali dirinya sendiri dan lingkungan sekitarnya (Edwin, 2017). Penelitian ini menggunakan lima indikator yang dikembangkan oleh (Nikolaou \& Tesaousis, 2002) yaitu sebagai berikut, persepsi tentang penilaian, dimana seorang auditor dalam melaksanakan pemeriksaan audit berlandaskan pada kesadaran emotional di dalam penilaiannya. Kontrol emosional, dimana seorang auditor dalam melaksanakan pemeriksaan audit mampu mengatur tingkat emotional di dalam diri sendiri. Penggunaan emosi, dimana seorang auditor dalam melaksanakan pemeriksaan audit mampu mengendalikan emotional di dalam diri sebagai motivasi kerja. Pengertian, dimana seorang auditor dalam melaksanakan pemeriksaan audit dengan mengendalikan sikap emotional sebagai sikap pengertian.

Menurut Robbins \& Judge (2011:38) adalah tindakan pengunduran diri secara permanen yang dilakukan oleh karyawan baik secara sukarela ataupun tidak secara sukarela. Turnover dapat berupa pengunduran diri, perpindahan keluar unit organisasi, pemberhentian atau kematian anggota organisasi. Adapun indikator-indikator dari turnover intention diadopsi dari Panagiotis et al. (2017) yang terdiri atas empat item pernyataan indikator antara lain: usia, dimana usia seorang auditor mempengaruhi tingkat turnover intention dalam melaksanakan audit. Lama kerja, dimana masa kerja seorang auditor mampu memberikan tekanan untuk melakukan turnover intention. Tingkat pendidikan, dimana pendidikan seorang auditor yang menunjukkan luas atau tidaknya pengetahuanya terhadap pekerjaan. Keterikatan terhadap perusahaan, perjanjian kerja yang dimiliki oleh seorang auditor memberikan peran dalam melaksanakan turnover intention.

Dengan pemberian skor 1 untuk pilihan Sangat Tidak Setuju (STS), skor 2 untuk pilihan Tidak Setuju (TS), skor 3 untuk pilihan Cukup Setuju (CS), skor 4 untuk pilihan Setuju (S) dan skor 5 untuk pilihan Sangat Setuju (SS).

Jenis data kuantitatif dan kualitatif yang dipergunakan seperti berupa angka-angka atau data yang dapat dihitung seperti data tanggapan responden terhadap kuesioner yang diberikan, jumlah sampel responden. Data kualitatif adalah data yang bukan merupakan angka dan tidak dapat dihitung yang mempunyai kaitan dengan permasalahan yang dibahas seperti sejarah singkat perusahaan, dan struktur organisasi perusahaan. Sumber data primer dan sekunder yang dipergunakan seperti observasi dan pemberian kuesioner kepada responden, sejarah berdirinya perusahaan, dan jumlah pelanggan.

Populasi adalah wilayah generalisasi yang terdiri atas objek/subjek yang mempunyai kualitas dan karakteristik tertentu yang ditetapkan oleh peneliti untuk dipelajari dan kemudian ditarik kesimpulannya (Sugiyono, 2017: 115). Populasi dalam penelitian ini adalah seluruh internal auditor PT. Bank BRI Kanwil Denpasar yang tergabung dalam Institut Auditor Publik Indonesia.

Jumlah sampel adalah 107 orang internal auditor dengan menggunakan pengambilan sampel dengan metode sensus (Sugiyono, 2017:17). Data yang 
dikumpulkan dalam penelitian ini menggunakan metode wawancara, pustaka dan kuesioner yang diberikan kepada responden yang telah dipilih.

Data yang dikumpulkan dalam penelitian ini akan dianalisis dengan cara regresi linier berganda, untuk mengetahui ketergantungan suatu variabel terikat dengan satu atau lebih variabel bebas. Analisis ini juga dapat menduga arah dari hubungan tersebut serta mengukur derajat keeratan hubungan antara satu variabel terikat dengan satu variabel bebas. Dalam analisis, peneliti dibantu dengan program computer Statitical Pacage of Social Science (SPSS) versi 15.0 for Windows.

$\mathrm{Y}=\alpha+\beta_{1} X_{1}+\beta_{2} X_{2}+\varepsilon$

Ghozali (2016: 134) Uji kelayakan model bertujuan untuk menguji apakah model yang digunakan dalam penelitian ini layak untuk digunakan atau tidak. Langkah-langkah dalam uji kelayakan model (Uji F) adalah sebagai berikut : menentukan taraf nyata sebesar $\leq 0,05$. Menentukan besarnya $p$-value yang diperoleh dari hasil pengujian dengan program SPSS.

Ghozali (2016: 65) Uji signifikansi parameter individual digunakan untuk menguji signifikansi koefisien regresi atau pengaruh secara parsial dari variabel bebas terhadap variabel terikat. Masing-masing hasil perhitungan setiap variabel ini kemudian dibandingkan nilai signifikansi yang diperoleh dengan menggunakan taraf nyata $\leq 0,05$.

\section{HASIL DAN PEMBAHASAN}

Karakteristik responden penelitian meliputi jenis kelamin, jenjang pendidikan dan lama bekerja, Karakteristik responden dapat dilihat pada Tabel 1, Tabel 2, dan Tabel 3.

\section{Tabel 1. Karakteristik Responden Berdasarkan Jenis Kelamin}

\begin{tabular}{ccc}
\hline Jenis Kelamin & Jumlah (Orang) & Persentase (\%) \\
\hline Laki-Laki & 67 & 69,8 \\
Perempuan & 29 & 30,2 \\
Total & 96 & 100 \\
\hline
\end{tabular}

Sumber: Data Penelitian, 2019

Tabel 1 menunjukan proporsi auditor laki-laki dan perempuan berdasarkan jenis kelamin, diketahui jumlah auditor laki-laki sebanyak 67 orang responden $(69,8 \%)$ dan auditor perempuan sebanyak 29 orang responden $(30,2 \%)$.

Tabel 2. Karakteristik Responden Berdasarkan Jenjang Pendidikan

\begin{tabular}{ccc}
\hline Pendidikan Terakhir & Jumlah (Orang) & Persentase (\%) \\
\hline Diploma 3 & - & $0 \%$ \\
S1 & 84 & 87,5 \\
S2 & 12 & 12,5 \\
Total & 96 & 100 \\
\hline
\end{tabular}

Sumber: Data Penelitian, 2019

Tabel 2 berfungsi untuk mengetahui jenjang pendidikan yang dimiliki responden, dimana tingkat pendidikan Diploma tidak ada (0\%), S1 sebanyak 84 orang $(87,5 \%)$ dan S2 sebanyak 12 orang $(12,5 \%)$. 
Tabel 3. Karakteristik Responden Berdasarkan Lama Bekerja

\begin{tabular}{ccc}
\hline Pengalaman Bergabung Dalam Tim Audit & Jumlah (Orang) & Persentase (\%) \\
\hline Kurang dari 5 Tahun & 37 & 38,5 \\
$>5$ s/d 10 tahun & 59 & 61,4 \\
Total & 96 & 100 \\
\hline
\end{tabular}

Sumber: Data Penelitian, 2019

Tabel 3 berfungsi untuk mengetahui lama responden bergabung dalam suatu tim audit, dimana tim audit kurang dari atau sama dengan lima tahun sebanyak 37 orang (38,5\%). Responden yang tergabung dalam tim audit lebih dari lima tahun sampai 10 tahun sebanyak 59 orang $(61,4 \%)$.

Untuk mengukur nilai sentral dari distribusi data dapat dilakukan dengan pengukuran rata-rata (mean) sedangkan standar deviasi merupakan perbedaan nilai data yang diteliti dengan nilai rata-ratanya. Hasil statistik deskriptif dapat dilihat pada Tabel 3.

Tabel 4. Hasil Statistik Deskriptif

\begin{tabular}{lccccc}
\hline \multicolumn{1}{c}{ Variabel } & N & Min. & Max. & Mean & Std. Deviasi \\
\hline Stress kerja & 96 & 2.20 & 5.00 & 3.6167 & 0.66025 \\
Emotional intelligence & 96 & 2.25 & 4.75 & 3.7109 & 0.67797 \\
Turnover intention & 96 & 2.00 & 5.00 & 3.6589 & 0.73190 \\
\hline
\end{tabular}

Sumber : Data Penelitian, 2019

Tabel 4 dapat dilihat bahwa variabel stress kerja $\left(X_{1}\right)$ memiliki nilai minimum sebesar 2.00, nilai maksimum sebesar 5.00, mean sebesar 3.6167, dan standar deviasi sebesar 0.66025 . Ini berarti bahwa terjadi perbedaan stress kerja yang diteliti terhadap nilai rata-ratanya sebesar 0.66025 .

Variabel emotional intelligence $\left(\mathrm{X}_{2}\right)$ memiliki nilai minimum sebesar 2.25, nilai maksimum sebesar 4.75, mean sebesar 3.7109, dan standar deviasi sebesar 0.67797. Ini berarti bahwa terjadi perbedaan nilai emotional intelligence yang diteliti terhadap nilai rata-ratanya sebesar 0.67797 .

Variabel turnover intention $(\mathrm{Y})$ memiliki nilai minimum sebesar 2.00, nilai maksimum sebesar 5.00, mean sebesar 3.6589, dan standar deviasi sebesar 0.73190. Ini berarti bahwa terjadi perbedaan nilai turnover intention yang diteliti terhadap nilai rata-ratanya sebesar 0.73190 .

Hasil Analisis Regresi Linear Berganda.

Tabel 5. Rangkuman Hasil Analisis Regresi Linear Berganda

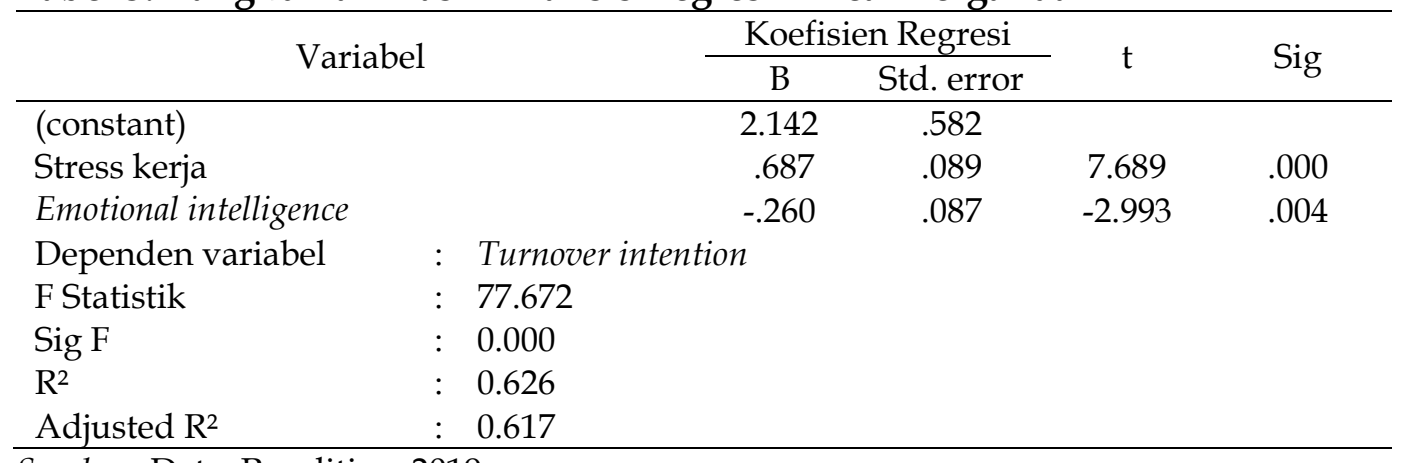

Sumber : Data Penelitian, 2019 
Berdasarkan Tabel 5 dapat ditulis persamaan regresi linear berganda sebagai berikut.

$$
Y=2,142+0,687 X_{1}-0,260 X_{2}
$$

Keterangan :

$\mathrm{Y}=$ Turnover intention

$\mathrm{X}_{1}=$ Stress kerja

$\mathrm{X}_{2}=$ Emotional intelligence

$\mathrm{R}^{2}=$ Koefisien determinasi

Berdasarkan persamaan hasil regresi linear berganda melalui uji SPSS, dapat dijelaskan hal-hal sebagai berikut.

Nilai konstanta sebesar 2,142 menunjukan bahwa bila stress kerja $\left(\mathrm{X}_{1}\right)$, emotional intelligence $\left(\mathrm{X}_{2}\right)$ sama dengan nol, maka nilai turnover intention $(\mathrm{Y})$ konstant sebesar 2,142 satuan.

Nilai koefisien $\beta_{1}=0,687$ berarti menunjukkan bila stress kerja $\left(X_{1}\right)$ bertambah 1 satuan, maka nilai dari turnover intention (Y) akan mengalami kenaikan sebesar 0,687 satuan dengan asumsi variabel bebas lainnya konstan.

Nilai koefisien $\beta_{2}=-0,260$ berarti menunjukkan bila emotional intelligence $\left(X_{2}\right)$ bertambah 1 satuan, maka nilai dari turnover intention $(\mathrm{Y})$ akan turun sebesar 0,260 satuan dengan asumsi variabel bebas lainnya konstan.

Pengujian ini dilakukan untuk mengetahui tingkat signifikansi pengaruh variabel bebas secara bersama (simultan) terhadap variabel terikat. Uji F dilakukan dengan membandingkan nilai $F_{\text {hitung }}$ dengan nilai $F_{\text {tabel }}$ pada taraf signifikansi 0,05 . Berdasarkan hasil perhitungan regresi linear berganda yang dirangkum pada lampiran 6 dapat diketahui bahwa $F_{\text {hitung }}=77,672$ dengan nilai signifikansi 0,000 $<0,05$ maka dapat disimpulkan stress kerja, emotional intelligence berpengaruh signifikan secara simultan terhadap turnover intention.

Hipotesis ini menyatakan bahwa stress kerja berpengaruh terhadap turnover intention dengan tingkat signifikansi sebesar 0,000 $<0,05$ maka $\mathrm{H}_{1}$ diterima. Artinya berpegaruh erat, dan signifikan dalam arti kedua variabel antara stress kerja dengan turnover intention saling berpengaruh besar/erat satu sama lain dengan didasarkan pada perhitungan olah data statistik yang signifikan.

Pengujian thitung pada variabel emotional intelligence $\left(\mathrm{X}_{2}\right)$

Hipotesis ini menyatakan bahwa emotional intelligence berpengaruh negatif terhadap turnover intention dengan tingkat signifikansi sebesar 0,004 < 0,05 maka $\mathrm{H}_{1}$ diterima. Artinya berpegaruh erat dan signifikan dalam arti kedua variabel antara emotional intelligence dengan turnover intention saling berpengaruh besar/erat satu sama lain dengan didasarkan pada perhitungan olah data statistik yang signifikan.

Hipotesis ini menyatakan bahwa stress kerja berpengaruh terhadap turnover intention dengan tingkat signifikansi sebesar 0,000 $<0,05$ maka $\mathrm{H}_{1}$ diterima. Attitude change theory merupakan model yang sering digunakan dalam menjelaskan hubungan antara stress kerja dan hasil pekerjaan (Alan \& Todd, 2011).

Stress kerja yang dirasakan auditor internal berasal dari berbagai sebab, misalkan dalam penelitian ini penyebab stress kerja yang dirasakan auditor berasal dari hubungan sosial sesama rekan kerja, sebagai contoh dalam penyelesaian laporan audit kurangnya kerja sama dalam penyusunannya 
sedangkan date line pelaksanaan audit sudah selesai baik waktu pelaksanaan audit dengan berbagai hasil temuan. Auditor merasa kurangnya waktu karena pekerjaan yang terlalu banyak yang sering dibebankan pada satu individu saja sedangkan waktu pelaporan yang dituntut harus selesai tepat pada waktunya, hal ini yang akan meningkatkan rasa stress pada auditor sehingga menimbulkan perilaku turnover intention internal auditor. Menurut Robbins dan Judge (2011:97) perilaku yang berlebihan akan menempatkan tuntutan yang tidak dapat dicapai, yang mengakibatkan hasil pekerjaan menurun. Hal ini relevan dengan kejenuhan kerja sangat besar akan menyebabkan tingkat stres yang tinggi yang berpengaruh terhadap karakteristik personal auditor sehingga melakukan perilaku disfungsional audit (Cheng \& Franz, 2013).

Beberapa penelitian seperti penelitian Edwin (2017) stress kerja didefinisikan sebagai suatu kondisi di mana seorang individu mengalami role conflict dan role ambiguity. Frengky (2012) dengan judul penelitiannya menyatakan stress kerja memiliki pengaruh terhadap perilaku turnover intention auditor. Shaini dan Wijana (2017) menyatakan stress kerja memiliki pengaruh terhadap perilaku turnover intention auditor. Muhammad et al. (2017) membuktikan bahwa terdapat pengaruh positif stress kerja terhadap perilaku turnover intention auditor yang memiliki arti meningkatnya stress kerja yang dialami auditor akan cenderung meningkatkan perilaku turnover intention.

Hipotesis ini menyatakan bahwa emotional intelligence berpengaruh negatif terhadap turnover intention dengan tingkat signifikansi sebesar 0,004 < 0,05 maka $\mathrm{H}_{1}$ diterima. Teori disonansi kognitif dapat menjelaskan bahwa emotional intelligence merupakan upaya dalam memecahkan masalah moral dengan menggunakan logika yang sehat. Perilaku emotional intelligence yang dirasakan auditor internal berasal dari berbagai sebab, misalkan banyak temuan audit yang harus dilaporkan pada hasil temuan, akan tetapi dari hati nurani yang paling dalam auditor internal dipengaruhi oleh emotional intelligence untuk mengambil keputusan yang akan memberatkan berbagai pihak, hal ini membuat auditor internal harus berlandaskan pada kesadaran emotional di dalam penilaian temuan audit, baik dari pengendalian emotional dalam melakukan pemeriksaan audit, pengumpulan data audit serta pengambilan keputusan audit yang bertujuan untuk mencapai sasaran kerja yang baik untuk perusahaan akan tetapi akan berdampak negatif terhadap berbagai pihak yang dilaporkan, dalam berlogika secara sehat seseorang harus mampu memahami dengan baik masalah yang sedang dihadapi, internal auditor harus mampu mengendalikan emotional yang paling dalam untuk mencapai sasaran kerja yang baik sebelum memutuskan pemecahan masalah seperti apa yang akan diambilnya sehingga memiliki hasil yang berkualitas dan menghindari terjadinya perilaku disfungsional auditor (Sartika, 2013).

Hasil penelitian ini sama dengan penelitian Jichul \& Thomas (2016) menyatakan emotional intelligence memiliki pengaruh terhadap perilaku turnover intention auditor. Panagiotis et al. (2017) membuktikan bahwa terdapat pengaruh emotional intelligence terhadap perilaku turnover intention auditor. Brunetto et al. (2012) dalam penelitiannya menyatakan emotional intelligence memiliki pengaruh terhadap perilaku turnover intention auditor. 


\section{SIMPULAN}

Berdasarkan pada pembahasan pada bab-bab sebelumnya, maka adapun hal-hal yang dapat disimpulkan yaitu stress kerja berpengaruh positif signifikan terhadap turnover intention internal auditor di PT Bank BRI Kantor Wilayah Denpasar. Artinya meningkatnya tingkat stress yang dialami oleh internal auditor akan meningkatkan perilaku turnover intention internal auditor. Emotional intelligence berpengaruh negatif signifikan terhadap turnover intention internal auditor di PT Bank BRI Kantor Wilayah Denpasar. Artinya baiknya pengendalian emotional intelligence internal auditor akan menurunkan perilaku turnover intention internal auditor.

Berdasarkan simpulan, saran-saran yang dapat diberikan Seorang auditor yang mengalami stress kerja cenderung mempermasalahkan tuntutan pekerjaannya yang tidak sesuai dengan benefit yang diterima, sebagai pihak yang bertanggung jawab kantor Inspeksi PT Bank BRI harus memperhatikan segala pekerjaan yang dibebankan kepada auditor dengan menyesuaikan pada benefit yang diterima internal auditor seperti adanya pengakuan dan penghargaan bagi internal auditor yang mampu menyelesaikan jumlah pemeriksaan audit yang dibebankan sesuai waktu pemeriksaan pelaporan, memberikan SPJ (surat perintah jalan) dalam membantu pihak auditor untuk bekerja secara baik serta biaya yang dibutuhkannya selama melaksanakan audit.

Emotional intelligence yang menjadi perhatian sampai saat ini adalah sikap emosi di dalam diri sendiri yang dimiliki oleh seorang internal auditor dalam melaksanakan pekerjaannya. Sebagai pihak yang bertanggung jawab kantor Inspeksi PT Bank BRI harus melakukan pelatihan secara berkala terkait sikologis seorang internal auditor sehingga mampu untuk berfikir positif, mengelola emosi dengan bijak, menjaga etika, dan menjaga harga diri yang akan membantu seorang internal auditor untuk menurunkan sikap yang tidak baik seperti turnover intention.

\section{REFERENSI}

Alkautsar, Muslim., 2014. Locus of Control, Commitment Profesional and Dysfunctional Audit Behaviour. International Journal of Humanities and Management Sciences. 2(1): h: 35-38

Anggriawan, Eko Ferry. 2014. Pengaruh Pengalaman Kerja, Skeptisme Profesional dan Tekanan Waktu terhadap Kemampuan Auditor dalam Mendeteksi Fraud (Studi Empiris pada Kantor Akuntan Publik di DIY). Jurnal Nominal Akuntansi. 3(2): h: 101-116

Arens, Alvin A. Elder, Randal J dan Beasley, Mark S. 2008." Auditing dan Jasa Asuransi Pendekatan Terintegrasi". Jilid 2, Edisi keduabelas, Erlangga.

Brunetto Yvonne, Stephen T.T. Teo, Kate Shacklock, Rod Farr-Wharton. 2012. Emotional intelligence, job satisfaction, well-being and engagement: explaining organisational commitment and turnover intentions in policing. Human Resource Management Journal. 22(4): h: 428-441

Casmini. 2007. Emotional Parenting. Yogyakarta : Pilar Medika 
Herda, David N., Kasey A. Martin. 2016. The Effects of Auditor Experience and Professional Commitment on Acceptance of Underreporting Time: A Moderated Mediation Analysis. International Journal of American Accounting Association. 10(2): h: 14-27

Departemen Pendidikan dan Kebudayaan. 1988. Kamus Besar Bahasa Indonesia. Jakarta: Departemen Pendidikan dan Kebudayaan.

Edwin Faisal. 2017. Peran Kecerdasan Emosional dalam memoderasi Pengaruh Stres Kerja Terhadap Kinerja Karyawan (Studi pada Asri Medical Center Yogyakarta). Jurnal Ekonomi dan Keuangan. 2(1): h: 1 - 18

Faisal. 2007. Tekanan Pengaruh Sosial dalam Menjelaskan Hubungan Moral Reasoning Terhadap Keputusan Auditor. Jurnal Akuntansi dan Keuangan. 4(1): h: 25-46

Sanjaya. Frengky., 2012. Peran Kecerdasan Emosional pada Stres Kerja. Jurnal Dinamika Manajemen. 3(2): h: 155-163

Ghozali, Imam. 2009. Aplikasi Analisis Multivariate dengan Program SPSS. Edisi kc2. Semarang: Badan Penerbit Universitas Diponegoro.

Gorgens-Ekermans, Gina., Tamari Brand. 2015. Emotional intelligence as a moderator in the stress-burnout relationship: a questionnaire study on nurses. Journal of Clinical Nursing. 2(1): h:2275-2285

Ikatan Akuntansi Publik Indonesia. 2009. Kode Etik Profesi Akuntan Publik. Institut Akuntan Publik Indonesia. Jakarta.

lkhsan, Arfan. 2008. Metodologi Penelitian Auditorsi Keperilakuan. Edisi 1. Yogyakarta: Oraha Ilmu.

Ioannis, Nikolaou., Tsaousis Ioannis. 2002. Emotional Intellegence in The Workplace: Exploring its Effects on Occupational Strsss and Organizational Commitment. The International Journal of Organizational Analysis. 10(4): h: 327-342

Jichul Jang, R. Thomas George. 2016. The Relationship of Emotional Intelligence to Job Stress, Affective Commitment, and Turnover Intention among Restaurant employees. International Journal of American Accounting Association. 1(4): h: 1-5

Kasmir. 2014. Dasar-Dasar Perbankan. Edisi Revisi, Cetakan ke duabelas, PT. RajaGrafindo Persada, Jakarta

Kompas.com. Di unduh dari http://health.kompas.com/read/2018/04/04/10500266/harapan.bagi.pa sien. kanker.stadium.lanjut.

Kreitner dan Kinicki. 2008. Perilaku Organisasi, Jakarta. Selemba Empat

Kustinah Siti. 2013. The Influence of Dysfunctional Behavior And Individual Culture On Audit Quality. International Academic Journal of Scientific $\mathcal{E}$ Technology Research. 2(5): h: 118-125

Lord T Alan, F Todd Dezoort. 2011. The Impact of Commitment and Moral Reasoning on Auditors Response to Social Influence Pressure. International Journal of Accounting, Organization and Society. 2(6): h: 215-235

Lu, Yong., Xiao-Min Hu, Xiao-Liang Huang, Xiao-Dong Zhuang, Pi Guo, Li-Fen Feng, Wei Hu, Long Chen, Huachun Zou, Yuan-Tao Hao. 2017. The relationship between job satisfaction, work stress, work-family conflict, 
and turnover intention among physicians in Guangdong, China: a crosssectional study. British Journal of Sports Medicine. 3(6): pp.1-12

Mangkunegara, A. A. Anwar Prabu. 2011. Manajemen Sumber Daya Manusia Perusahaan. Bandung: PT. Remaja Rosdakarya

Maryam, Sadeghi., Jamal Barzegari Khanagha, Mahmoud Naderibeni. 2014. Professional Commitment on Dysfunctional Audit Behaviour In audit organizations of Isfahan Public Accountancy. Interdisciplinary Journal of Contemporary Research in Business. 5(9): h: 275-283

Medhat Endrawes, Gary S. Monroe. 2015. Professional Scepticism of Auditors: A Cross-Cultural Experiment. International Journal of American Accounting Association. 51(2): h: 1-41

Michael Gaffikin, Lindawati. 2012, The Moral Reasoning of Public Accountants in the Development of a Code of Ethics: the Case of Indonesia. International Journal of Australasian Accounting, Business and Finance. 6(1): h: 3-28

Mulyadi, 2011. Auditing. Edisi ke-6. Jakarta: Salemba Empat.

Mustika, Sulastri., Dandes Rifa, Herawati. 2015. Pengaruh Moral Reasoning dan Professional Skepticism Auditor Pemerintah Terhadap Kualitas Audit Laporan Keuangan Pemerintah Daerah di Kota Padang. Jurnal Akuntansi dan Keuangan Indonesia. 2(1): h: 4-29

Nelson. Mark W., 2009. A Model and Literature Review of Professional Skepticism in Auditing. International Journal of American Accounting Association. 28(2): h: 1-34

Quadackers Luc, Tom Groot, Arnold Wright. 2008. Auditors' Skeptical Characteristics and Their Relationship to Skeptical Judgments and Decisions. International Journal of Accounting, Organization and Society. 3(1): h: $1-47$

Rieke Sri, Rizki Asti Karini. 2015. Stress Role and Dysfunctional Behavior on The Performance of Internal Auditor. Journal of Trikonomika. 14(2): h: 129-137

Robbins, S.P., and Judge, T.A. 2011. Perilaku Organisasi, Edisi Kedua belas,Jakarta: Salemba Empat

Rustiarini, Ni Wayan., 2014. Sifat Kepribadian sebagai Pemoderasi Hubungan Stres Kerja dan Perilaku Disfungsional Audit. Jurnal Akuntansi dan Keuangan Indonesia. 11(1): h: 1-19

Sartika. 2013. Pengaruh Sifat Mchiavellian dan Perkembangan Moral terhadap Perilaku Disfungsional. (Studi Empiris pada Perusahaan Manufaktur Kota Padang). Jurnal Simposium Nasional Akuntansi. 4(2): h:1-32

Sawyer, Lawrence B. 2009. Internal Auditing. Buku Dua. Edisi Lima. Jakarta: Salemba Empat

Septiani, Indri Ni Made, Sukartha, I Made. 2017. Pengaruh Kompleksitas Audit dan Skeptisme Profesional Auditor pada Penerimaan Perilaku Disfungsional Audit. Jurnal Akuntansi Universitas Udayana. 18(1): h: 471499

Setya Devi, Mahatma Luh,. Suaryana I G.N.A,. 2016. Time Budget Pressure Memoderasi Pengaruh Karakteristik Personal Auditor terhadap Penerimaan Perilaku Disfungsional Audit. Jurnal Akuntansi Universitas Udayana. 15(3): h: 1994-2023 
Shaini Kusuma Sudarmawan, Putu., Wijana Asmara Putra, I Nyoman. 2017. Pengaruh Role Stress pada Turnover Intentions Auditor dengan Komitmen Afektif sebagai Variabel Pemoderasi. Jurnal Akuntansi Universitas Udayana. 19(3): h: 2000-2027

Sudarshan K. Pillalamarri. 2015. The Role of Moral Reasoning and Order Effects on Ethical Decision-Making Ability: Novice vs. Experienced Accounting Students. International Journal of American Accounting Association. 4(2): h: 122

Sugiyono. 2017. Metode Penelitian Bisnis. Bandung: CV. Alfabeta.

Suriana AR. Mahdi. 2014. An Analyze Determinants Audit Quality With Moral Reasoning as the Moderating and Has a Specific Purpose. International Academic Journal of Scientific \& Technology Research. 11(1): h: 61 - 82

Syarhayuti, Faidul Adziem. 2016. Pengaruh Moral Reasoning, Skeptisme Profesional dan Kecerdasan Spiritual terhadap Kualitas Audit dengan Pengalaman Kerja Auditor sebagai variabel moderating di Inspektorat Provinsi Sulawesi Selatan. Jurnal Akuntansi Peradaban. 1(1): h: 128-148

Tangsakul Paneeda, Phaprukbaramee Ussahawanitchakit. 2015. Moral Reasoning of Tax Auditors in Thailand: An Empirical Investigation of the Antecedents and Consequences. International Journal of The Business and Management Review. 7(1): h: 134-142

Trivellas Panagiotis, Vassilis Gerogiannis and Sofia Svarna. 2017. The impact of Emotional Intelligence on job outcomes and turnover intention in Health Care. International Journal of American Accounting Association. 5(2): h: 1-4

Tugiman, Hiro. 2006. Standar Profesional Audit Internal. Yogyakarta: Kanisisus

Umar, Husein. 2007. Metode Penelitian untuk Skripsi dan Tesis Bisnis. Edisi Bam ke7. PT Raja Grafmdo Persada. Jakarta

Waheed Akhtar Muhammad, Atif Shabir, Muhammad Shahid Safdar and Muhammad Saeed Akhtar. 2017. Impact of Emotional Intelligence on Turnover Intentions: The Role of Stress and Perceive Organizational Support. Journal of Accounting \& Marketing. 6(4): h: 1-7

Ying, Cheng., Franz Waldenberger. 2013. Does training affect individuals' turnover intention? Evidence from China. Journal of Chinese Human Resources Management. 4(1): h: 16 - 38

Yuen., Desmond C.Y., Philip K.F. Law, Chan Lu, Jie Qi Guan. 2012. Dysfunctional Auditing Behaviour: Empirical Evidence on Auditors' Behaviour in Macau. International Journal of Accounting and Information Management. 4(5): h: 1-20

Zakaria Balkish, Nor., Nurhidayah Yahya, Kalsom Salleh. 2013. Dysfunctional Behavior among Auditors: The Application of Occupational Theory. Journal of Basic and Applied Scientific Research. 3(9): h: 495-503 